\title{
PERANAN GURU IPA DAN IPS DALAM MENANAMKAN NILAI YANG TERKANDUNG DALAM KONTEN IPA DAN IPS DI MADRASAH IBTIDA'IYAH
}

\author{
Nafia Wafiqni \& Burhanudin Milama \\ Universitas Islam Negeri (UIN) Syarif Hidayatullah Jakarta \\ Email: nafia_chant@yahoo.co.id; burhanmilama@yahoo.com
}

\begin{abstract}
This study aimed at determining the role of science and social studies teachers in instilling the values contained in science and social studies content at Government Elementary School. The method used in this research was descriptive qualitative. Through a case study, this qualitative approach was intended to gain in dept understanding of social situation, and find patterns, hypotheses and theories. Subjects in this study were 10 teachers who teach science and social studies at Islamic elementary schools that were selected from randomly chosen elementary schools from North Jakarta, South Jakarta, Central Jakarta, West Jakarta and East Jakarta. The results of the study revealed that responsibility, collaborative work, mutual respect, and respect could be developed by teachers through teaching and learning process. Yet, other values that were specifically generated from the material content of science and social studies have not been tried out to be developed except in teachers' lesson plans.
\end{abstract}

Keywords: planting value, the content value in science and social studies lessons, teachers in Elementary School

\begin{abstract}
Abstrak: Penelitian ini bertujuan untuk mengetahui peranan guru IPA dan IPS dalam menanamkan nilai yang terkandung dalam konten IPA dan IPS di Madrasah Ibtidaiyah. Metode yang digunakan dalam penelitian ini adalah penelitian deskriptif kualitatif. Dalam penelitian kualitatif ini peneliti bermaksud untuk memahami situasi sosial secara mendalam, menemukan pola, hipotesis dan teori. Sedangkan jenis penelitiannya adalah studi kasus. Subjek dalam penelitian ini yakni 10 guru yang mengajar mata pelajaran IPA dan IPS di Madrasah Ibtidaiyah yang dipilih secara acak. MI yang diobservasi adalah satu sekolah yang menjadi perwakilan di Jakarta Utara, Jakarta Selatan, Jakarta Pusat, Jakarta Barat, dan Jakarta Timur. Dari hasil penelitian terungkap bahwa untuk penanaman karakter yang sifatnya terlihat sudah dilakukan oleh guru walaupun belum bervariasi. Karakter yang dikembangkan oleh guru seperti tanggung jawab, bekerja sama,saling menghormati, dan menghargai. Sedangkan untuk penggalian nilai yang terkandung dalam konten IPA dan IPS itu sendiri belum banyak dilakukan oleh guru. Hal ini terlihat dari RPP yang dibuat oleh guru-guru tersebut.
\end{abstract}

Kata Kunci: penanaman nilai, konten nilai pada pelajaran IPA dan IPS, guru di Madrasah Ibtidaiyah

\section{Pendahuluan}

Di lembaga pendidikan, kebutuhan akan pendidikan akhlak telah diakomodasikan secara terbatas dengan cara mengintegrasikan pendidikan budi pekerti ke dalam Pendidikan Agama Islam (PAI). Sebagai realisasinya, materi PAI yang diajarkan di sekolah-sekolah mencantumkan sub pembahasan tentang nilainilai budi pekerti dan berupaya menanamkan nilai-nilai pendidikan budi pekerti dengan penyampaian kisah teladan dan pembiasaan budi pekerti.
Jika dicermati, pendidikan budi pekerti merupakan pendidikan nilai-nilai luhur yang berakar dari agama, adat istiadat dan budaya bangsa Indonesia dalam rangka mengembangkan kepribadian peserta didik supaya menjadi manusia yang baik. Ruang lingkup pendidikan budi pekerti menurut Zakaria adalah penanaman dan pengembangan nilai, sikap dan perilaku peserta didik sesuai nilai-nilai budi pekerti luhur. ${ }^{1}$ Sejumlah nilai budi pekerti yang perlu

\footnotetext{
${ }^{1}$ Teuku Ramli Zakaria, "Penilaian Sikap dan Nilai dalam Pembelajaran Matematika dan Sains", dalam Makalah
} 
ditanamkan adalah sopan santun, berdisiplin, berhati lapang, berhati lembut, beriman dan bertaqwa, berkemauan keras, tanggung jawab, tenggang rasa, jujur, sabar, kebersamaan, rendah hati, sportif, taat asas, tekun dan tepat janji.

Tanggung jawab untuk membina moral siswa menjadi tidak semata-mata berada di pundak guru agama dan guru kewarganegaraan, tetapi juga menjadi bagian tanggung jawab dari seluruh guru dan warga sekolah lainnya. Pembinaan budi pekerti siswa tidak terbatas ketika berlangsungnya proses penyampaian materi budi pekerti yang dilakukan oleh guru pelajaran agama maupun kewarganegaraan, tetapi perlu didukung oleh guru lain dengan cara menyisipkan nilai-nilai akhlak atau budi pekerti pada mata pelajaran yang dipegangnya.

Oleh karena itu, setiap pelajaran seyogyanya tidak hanya mengandung substansi pelajaran yang bersifat kognitif, namun di balik hal-hal yang bersifat kognitif terdapat sejumlah nilai dasar yang harus diketahui oleh siswa. Ilmu Pengetahuan Alam dan Ilmu Pengetahuan Sosial merupakan mata pelajaran yang tidak bebas dari nilai. Banyak nilai-nilai yang terkandung dalam konten IPA dan IPS, seperti kebersamaan, pendidikan, akhlak yang baik, kejujuran, kecermatan, dan banyak nilai yang lain. Begitu juga dengan mata pelajaran yang ada di luar IPA dan IPS semuanya banyak mengajarkan nilainilai yang terkandung dalam kontennya.

Dengan model pembelajaran yang integral itu diasumsikan setiap materi pelajaran akan mengimplikasikan nilai-nilai budi pekerti sehingga terjadi inter-colleration (saling mengisi) dan inter-connected (saling berhubungan) antara pendidikan agama dengan mata pelajaran lainnya. Artinya nilai-nilai budi pekerti tidak hanya dibingkai dalam wadah pelajaran Pendidikan Agama, tetapi dapat juga diintegrasikan ke dalam mata pelajaran lainnya. Upaya-upaya terobosan ini diyakini akan

disampaikan dalam Seminar Nasional dengan Tema Pendidikan Nilai, 2008, Universitas Islam Negeri Jakarta, h. 1. membawa pengaruh optimal bagi pembentukan kualitas moral peserta didik.

Berdasarkan latar belakang di atas, peranan guru-guru di luar mata pelajaran agama dan kewarganegaraan sangat membantu dalam menanamkan nilai-nilai budi pekerti sehingga berdampak terhadap kualitas akhlak siswa, tak terkecuali guru IPA dan IPS. Namun, perlu diadakan penelitian untuk menyimpulkan apakah guru IPA dan IPS sudah mencoba mengintegrasikan nilai yang terkandung dalam konten IPA dan IPS tersebut atau belum, sehingga penulis memandang penting meneliti tentang: "Peranan Guru IPA dan IPS dalam Menanamkan Nilai yang Terkandung dalam Konten IPA dan IPS di MI”

\section{Landasan Teori Hakikat Nilai}

Nilai adalah suatu pengertian atau penafsiran yang digunakan untuk memberikan penghargaan terhadap barang atau benda, manusia menganggap sesuatu bernilai karena ia merasa memerlukannya atau menghargainya. Menurut Kupperman dalam Yudianto, menyatakan bahwa nilai adalah patokan normatif yang mempengaruhi manusia dalam menentukan pilihannya di antara cara-cara tindakan alternatif. ${ }^{2}$ Manusia menjadikan nilai sebagai acuan dalam mengambil suatu tindakan ataupun pilihan.

Nilai didefinisikan sebagai suatu ide yang relatif konstan tentang suatu perilaku. Hal ini menunjukkan pada kriteria untuk menentukan tingkat kebaikan, harga, atau keindahan. Nilai adalah sistem kepercayaan yang membimbing orang untuk bertindak atau menghindari suatu tindakan atau mengenai suatu yang pantas atau tidak pantas dikerjakan, dimiliki, atau dipercayai. Nilai membimbing manusia dalam melakukan suatu tindakan atau untuk menghindari atau mengenai diri dari sesuatu.

\footnotetext{
2 Suroso Adi Yudianto, Strategi Belajar Mengajar Sains, (Bandung: Fakultas Tarbiyah IAIN Bandung, 2001), h. 45.
} 
Menurut Stevart dan Strong dalam Lamijan, nilai merupakan patokan atau prinsip-prinsip yang merupakan kriteria untuk menimbang atau menilai suatu hal apakah baik atau buruk, berguna atau sia-sia, dihargai atau tercela, atau antara keduanya, ${ }^{3}$ sehingga manusia dalam bertindak untuk melakukan sesuatu dibatasi oleh nilai-nilai yang ada. Menurut Kniker yang dikutip oleh Yudiyanto, nilai sebagai gabungan sikap-sikap yang menghasilkan perbuatan atau pilihan yang disengaja. ${ }^{4}$

Menurut Frankel dalam Zakaria, nilai adalah sebagai ukuran dari perbuatan, keindahan atau harga yang diakui oleh seseorang dan dia berusaha untuk berbuat sesuai dengan ukuran tersebut. Frankel juga mengatakan bahwa a value is an idea concept about what someone think is important in life, yaitu hubungan antara subjek dengan objek memiliki arti yang penting dalam kehidupan subjek. ${ }^{5}$

Jadi, nilai adalah patokan atau prinsip yang mempengaruhi manusia dalam melakukan tindakan, menimbang, atau menilai, suatu hal apakah baik atau buruk, pantas atau tidak pantas dikerjakan, dimiliki atau dipercayai, berguna atau sia-sia, dihargai atau tercela atau di antara keduanya. Secara garis besar nilai dibagi menjadi dua kelompok, yaitu:

1) Nilai-nilai Nurani (values of being)

Nilai-nilai nurani adalah nilai yang ada dalam diri manusia kemudian berkembang menjadi perilaku, serta cara kita memperlakukan orang lain. Yang termasuk nilai nurani adalah kejujuran, keberanian, cinta damai, keandalan diri, potensi, disiplin, tahu batas, kemurnian dan kesesuaian.

2) Nilai-nilai Memberi (values of giving)

Nilai-nilai memberi adalah nilai yang perlu dipraktikkan atau diberikan yang kemudian akan diterima sebanyak yang diberikan. Yang

\footnotetext{
${ }^{3}$ Lamijan, "Metode dan Teknik Pendidikan Nilai", dalam Jurnal Inkoma 13(1), 2002, h. 87.

${ }^{4}$ Suroso Adi Yudianto, Strategi Belajar Mengajar Sains, h. 86.

${ }^{5}$ Teuku Ramli Zakaria, "Penilaian Sikap dan Nilai dalam Pembelajaran Matematika dan Sains”, h. 97.
}

termasuk ke dalam nilai-nilai memberi adalah setia, dapat dipercaya, hormat, cinta, kasih sayang, peka, tidak egois, baik hati, ramah, adil dan murah hati.

\section{Macam-macam Nilai}

Macam-macam nilai dilihat dari berbagai sudut pandang, yaitu:

1) Dilihat dari segi kebutuhan hidup, nilai dikelompokkan menjadi: a) nilai biologis, b) nilai keamanan, c) nilai cinta kasih, d) nilai harga diri, d) nilai jati diri.

2) Dilihat dari kemampuan jiwa manusia, nilai dibedakan menjadi: a) nilai yang statik, seperti kognisi, emosi, dan psikomotor, b) nilai yang dinamik, seperti motivasi berafiliasi, motivasi berkuasa, motivasi berprestasi.

3) Dilihat dari pendekatan budaya manusia, nilai dibagi menjadi 7 , yaitu: a) nilai ilmu pengetahuan, b) nilai ekonomi, c) nilai keindahan, d) nilai politik, e) nilai keagamaan, f) nilai kekeluargaan, g) nilai kejasmanian.

4) Dilihat dari sifat "nilai", nilai dibagi menjadi tiga, yaitu: a) nilai-nilai subjektif, b) nilai-nilai objektit-rasional, c) nilai-nilai objektif-metafisik.

5) Dilihat dari sumbernya, nilai dibagi menjadi: a) nilai Ilahiyah (ubudiyah dan muamalah), b) nilai insaniyah.

6) Dilihat dari ruang lingkup keberlakuannya, nilai dibagi menjadi: a) nilai-nilai universal, dan b) nilai-nilai lokal.

7) Dilihat dari hakikatnya, nilai dibagi menjadi: a) nilai hakiki dan b) nilai instrumental.

Spranger dalam Yudianto, membagi nilai menjadi 6 macam, yaitu (1) nilai etika, (2) nilai ekonomi, (3), nilai sosial, (4) nilai kekuasaan, (5) nilai estetika, dan (6) nilai religius. ${ }^{6}$ Menurut Einten dalam Yudianto, nilai IPA meliputi:

\footnotetext{
${ }^{6}$ Suroso Adi Yudianto, Strategi Belajar Mengajar Sains, h. 35.
} 
a. Nilai Praktis

Nilai praktis merupakan nilai kemanfaatan dari suatu bahan ajar yang dikaitkan dengan segisegi kepraktisan bagi kehidupan manusia. Nilai praktis IPA adalah kandungan nilai yang berhubungan dengan aspek-aspek manfaat IPA dalam kehidupan. Sains dapat berkembang pesat karena memiliki nilai praktis, seperti sumber pangan, sandang, perumahan dan pengobatan/kesehatan. Sebagai contoh adanya obat untuk orang yang sakit, adanya tekonologi pembuatan jembatan, industri kendaraan, dll.

b. Nilai Intelektual

Nilai intelektual suatu bahan ajar adalah mengajarkan kecerdasan seseorang dalam menggunakan akalnya untuk memahami sesuatu dengan tidak mempercayai tahayul atau kebenaran mitos, tetapi agar lebih kritis, analitis dan kreatif terhadap pemecahan suatu masalah yang lebih efektif dan efisien. Selain itu, nilai intelektual berarti nilai kecerdasan pada manusia untuk mengambil sikap dan perilaku yang tepat, tidak percaya pada mistis atau hal-hal yang bersifat provokatif. Dengan demikian, segala permasalahan dipertimbangkan dengan akal sehat dan diselesaikan melalui proses berfikir kritis.

c. Nilai Sosial Politik Ekonomi

Nilai sosial politik suatu bahan ajar merupakan petunjuk untuk dijadikan pelajaran bagi hubungan interaksi manusia di bidang sosial, politik dan ekonomi, yang merupakan suatu model jalinan hubungan sesama manusia sebagai makhluk sosial yang tidak mungkin sendiri tetapi memerlukan peran serta orang lain dalam mewujudkan misi politik dan kemajuan ekonomi.

d. Nilai Pendidikan

Nilai pendidikan suatu bahan ajar merupakan kandungan nilai dari bahan ajar yang dapat memberikan inspirasi atau ide-ide atau gagasan untuk dimunculkan dalam rangka pemenuhan kebutuhan, keinginan dan hasratnya bagi kesejahteraan hidupnya, baik untuk pribadi maupun kepentingan bangsanya. Banyak sekali contoh nilai pendidikan dalam sains antara lain ketika siswa belajar konsep semut. Semut jika diperhatikan ketika bertemu sesama mereka maka akan selalu menyapa sehingga memberikan pendidikan kepada kita tentang pentingnya untuk bersosialisasi dan tetap menjaga persatuan.

e. Nilai Religius

Nilai religius menurut Einsten dalam Yudianto merupakan kandungan nilai yang dapat membangkitkan rasa percaya atau keyakinan bahwa suatu yang ada mesti ada yang menciptakannya atau mengaturnya, yang pada akhirnya timbul kesadaran adanya Allah. ${ }^{7}$ Semua yang diciptakan Allah di muka bumi ini memiliki nilai, sebagai contoh dalam pelajaran sains adalah ketika Allah menciptakan energi untuk memberikan kehidupan bagi manusia, Allah menciptakan hewan sebagai bahan pelajaran bagi manusia, Allah menciptakan udara.

Menurut Mauha dalam Gunawan, nilai Ilmu Pengetahuan Alam (IPA) mencakup lima nilai, yaitu: (1) nilai intelektual, (2) nilai praktis, (3) nilai pendidikan, (4) nilai sosio-politik ekonomi, dan (5) nilai religius. ${ }^{8}$

Terkait dengan Ilmu Pengetahuan Sosial, sebagai mata pelajaran di sekolah bukan saja mengembangkan nilai teoretik yang mengedepankan logika dan rasional, tetapi juga menjadi mata pelajaran yang dapat digunakan untuk mengembangkan nilai-nilai yang lain. Secara umum, pendidikan IPS memiliki tujuan yakni menjadikan peserta didik sebagai warga negara yang baik, dengan berbagai karakter yang berdimensi spiritual, personal, sosial, dan intelektual.

Menurut Jarolimelc pendidikan IPS juga mempunyai tujuan informasi dan pengetahuan (knowledge and information), nilai dan tingkah

\footnotetext{
${ }^{7}$ Suroso Adi Yudianto, Strategi Belajar Mengajar Sains), h. 22.

${ }^{8}$ Gunawan. "Penerapan Model Pembelajaran Integrasi Imtaq untuk Meningkatkan Motivasi dan Hasil Belajar Fisika Siswa di MA Dakwah Islamiyah Putra Kediri”, dalam Jurnal Kependidikan LPPM IKIP Mataram 4(2), 2005, h. 28.
} 
laku (attitude and values), dan tujuan keterampilan (skill): sosial, bekerja dan belajar, kerja kelompok, dan keterampilan intelektual. ${ }^{9}$ Adapun nilai-nilai yang dapat dikembangkan dalam pendidikan nilai di dalam pembelajaran IPS di antaranya adalah nilai teoritik, ekonomis, estetik, sosial, politik, dan agama.

\section{Strategi dalam Mengintegrasikan Nilai}

Ada lima strategi yang perlu diperhatikan
dan digunakan oleh guru dalam mengintegrasikan secara efektif nilai-nilai, yaitu:

1) Memberi teladan, dengan penghayatan dan pengamalan nilai-nilai kebaikan secara konsisten dalam kehidupan sehari-hari, sesuai dengan pepatah dan nilai budaya kita, bahwa guru adalah orang yang pantas digugu dan ditiru.

2) Memberi informasi verbal, dengan nasehat dan penjelasan-penjelasan, sesuai dengan perkembangan positif dan penalaran kedewasaan siswa.

3) Memberi ganjaran positif dan negatif (positive/negative reinforcement) untuk perilaku dan hasil belajar yang dicapai siswa.

4) Membiasakan siswa mengamalkan nilainilai yang ingin diintegrasikan dalam proses pembelajaran.

5) Menciptakan kondisi kondusif, yang memungkinkan dan memudahkan siswa dalam menghayati dan mengamalkan nilainilai kebaikan yang ingin diintegrasikan.

\section{Metode Penelitian}

Metode yang digunakan dalam penelitian ini adalah penelitian deskriptif kualitatif. Dalam penelitian kualitatif ini peneliti bermaksud untuk memahami situasi sosial secara mendalam, menemukan pola, hipotesis dan teori. Sedangkan jenis penelitiannya adalah studi kasus. Penelitian

\footnotetext{
9 John Jarolimelc, Social Studies in Elementary Education, (London: Mav Millan, 1986), p. 5-8.
}

studi kasus adalah studi yang mengeksplorasi suatu masalah dengan batasan terperinci, memiliki pengambilan data yang mendalam, dan menyertakan berbagai sumber informasi. Penelitian ini dibatasi oleh waktu dan tempat, dan kasus yang dipelajari berupa program, peristiwa, aktivitas, atau individu.

Penelitian ini akan dilaksanakan di Madrasah Ibtidaiyah yang ada di provinsi DKI Jakarta.

Penelitian dilakukan terhadap 10 guru yang mengajar mata pelajaran IPA dan IPS di Madrasah Ibtidaiyah yang dipilih secara acak. MI yang diobservasi adalah satu sekolah yang menjadi perwakilan di Jakarta Utara, Jakarta Selatan, Jakarta Pusat, Jakarta Barat, dan Jakarta Timur.

\section{Teknik Analisis Data}

Analisis data adalah proses mencari dan menyusun secara sistematis data yang diperoleh dari hasil wawancara, catatan lapangan, dan dokumentasi, dengan cara mengorganisasikan data ke dalam kategori, menjabarkan ke dalam unit-unit, melakukan sintesa, menyusun ke dalam pola, memilih mana yang penting dan yang akan dipelajari, dan membuat kesimpulan sehingga mudah dipahami oleh diri sendiri maupun orang lain.

Proses analisis data dilakukan berdasarkan pandangan dari Miles dan Huberman, yang mengemukakan bahwa aktivitas dalam analisis data kualitatif dilakukan secara interaktif dan berlangsung terus-menerus sampai tuntas, sehingga datanya sudah jenuh. ${ }^{10}$ Selanjutnya Miles dan Huberman menggambarkan proses analisis datanya sebagai berikut:

a. Data Collection

Data Collection diperoleh dari data yang dikumpulkan berdasarkan observasi, wawancara, dan studi dokumentasi.

\section{b. Data Reduction}

\footnotetext{
${ }^{10}$ Mathew B Miles and Michael Huberman, Qualitative Data Analysis: A Sourcebook of New Methods, (London: Sage Publication, Inc., 1984), p. 103.
} 
Data yang diperoleh dari lapangan jumlahnya cukup banyak untuk itu perlu dicatat secara teliti dan rinci. Mereduksi data berarti merangkum memilih hal-hal yang pokok, memfokuskan pada hal-hal yang penting, dicari tema dan polanya dan membuang yang tidak perlu. $^{11}$

\section{c. Data Display}

Setelah data direduksi, maka langkah selanjutnya adalah data disajikan dalam bentuk tabel, grafik, phie chard, pictogram, dan sejenisnya. Melalui penyajian data tersebut, maka data terorganisasikan, tersusun dalam pola hubungan, sehingga akan mudah dipahami.

\section{d. Conclusions}

Langkah terakahir dalam analisis data adalah penarikan kesimpulan dan verifikasi. Kesimpulan awal yang dikemukakan masih bersifat sementara, dan akan berubah bila tidak ditemukan bukti-bukti yang kuat yang mendukung pada tahap pengumpulan data berikutnya. Akan tetapi, apabila kesimpulan awal yang dikemukakan disertai dengan bukti yang valid dan konsisten, maka kesimpulan dianggap kredibel.

\section{Uji Keabsahan Data}

Uji keabsahan data yang digunakan dalam penelitian ini adalah uji kredibilitas data yang dilakukan dengan triangulasi. Triangulasi dalam pengujian kredibilitas ini diartikan sebagai pengecekan data dari berbagai sumber dengan berbagai cara, dan berbagai waktu.

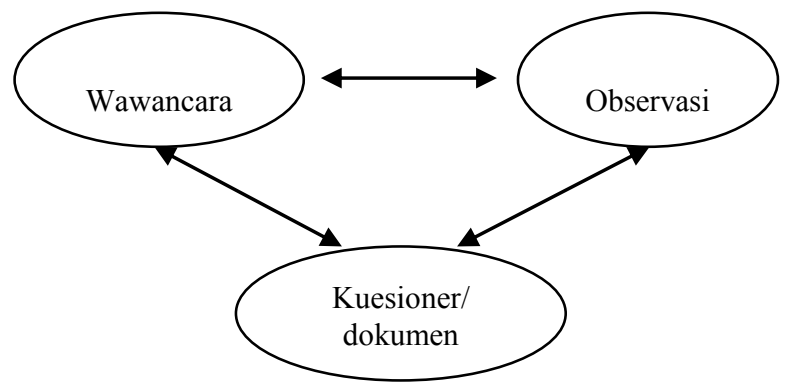

11 Emzir, Analisis Data: Metodologi Penelitian Kualitatif, (Jakarta: Rajawali Pers, 2011), h. 129.

\section{Analisis Data}

Data dalam penelitian ini diperoleh dari hasil wawancara terhadap guru lima orang guru IPA dan lima orang guru IPS dan dokumentasi berupa Rencana Pelaksanaan Pembelajaran (RPP) yang digunakan oleh guru IPA dan IPS. Berikut ini akan dianalisis hasil wawancara dan RPP yang diberikan:

1) Data Wawancara

a. Guru IPA

Wawancara dilakukan terhadap lima guru IPA yang dipilih secara acak di wilayah Jakarta

- Guru I (mewakili daerah Jakarta Pusat)

Guru ini memiliki gelar Sarjana Pendidikan adalah guru kelas yang mengajar mata pelajaran Matematika, IPA, IPS, Bahasa Indonesia, dan Agama dengan masa kerja 5 tahun. Namun, guru ini ditugaskan mengajar mata pelajaran IPA sekitar 4 bulan. Guru ini tidak memiliki pengalaman mengajar di tempat lain.

- Guru II (mewakili daerah Jakarta Utara)

Guru ini memiliki gelar Sarjana Pendidikan Islam, pengalaman mengajar 17 tahun dengan lama mengajar untuk mata pelajaran IPA 12 tahun, selain mata pelajaran IPA guru ini juga pernah mengajar mata pelajaran Penjaskes selama 2 tahun.

- Guru III (mewakili daerah Jakarta Timur)

Guru dengan gelar Sarjana Pendidikan Islam ini, memiliki pengalaman mengajar selama 19 tahun sebagai guru kelas. Selain mengajar di MI, guru ini juga mengajar beberapa MTs pada mata pelajaran Biologi, Fisika, dan Agama.

- Guru IV (mewakili daerah Jakarta Barat)

Guru ini adalah seorang Sarjana Pendidikan Islam yang mengajar dari tahun 1994 (17 tahun), mengajar mata pelajaran IPA sudah 10 tahun. Selain IPA guru ini mengajar Bahasa Indonesia, dan Matematika.

- Guru V (mewakili daerah Jakarta Selatan)

Guru ini adalah seorang Sarjana Pendidikan Islam yang mengajar dari tahun 1998. Mengajar 
mata pelajaran IPS sudah 5 tahun, sebelumnya mengajar Bahasa Arab dan IPS sebagai guru pengganti.

Dari hasil wawancara dengan lima orang guru IPA yang menjadi perwakilan dari lima wilayah di daerah Khusus Ibukota Jakarta ditemukan bahwa mayoritas guru, sebanyak 4 orang belum pernah mendengar informasi tentang pendidikan nilai dan hanya satu orang guru yang pernah mendengar "saya membaca ada NKBB (Nilai Karakter Budaya Bangsa) pada saat seminar tentang Menumbuhkan Bakat dan Minat Anak". ${ }^{2}$

Beberapa nilai yang terkandung pada setiap mata pelajaran menurut para guru IPA di antaranya adalah: kerjasama, ketelitian, disiplin, tanggung jawab, agama/religi, kejujuran, moral, kreativitas, toleransi, dan saling menghormati.

Seluruh guru IPA menyatakan bahwa tidak ada mata pelajaran di sekolah yang bebas dari kandungan nilai. Salah satu alasaan yang disampaikan guru IPA adalah karena di dalam materi yang disampaikan kepada siswa, isi dan tujuannya untuk mengubah perilaku siswa. ${ }^{13}$

Menurut guru-guru IPA, beberapa manfaat mengajarkan IPA dengan memasukkan nilai-nilai yang terkandung di dalamnya adalah sebagai berikut:

a) Secara intelek siswa mengetahui alam dan harus bertanggung jawab terhadap alam sebagai khalifah. ${ }^{14}$

b) IPA berhubungan dengan alam, karenanya manusia harus pandai memanfaatkan alam dan bermanfaat bagi pengembangan serta pelestarian alam sekitar (simbiosis mutualisme). ${ }^{15}$

c) Melalui tugas praktikum IPA, siswa dapat belajar lebih bermakna tidak verbalis, siswa menjadi lebih dahulu memahami cara kerjanya sebelum diucapkan atau dipresentasikan. ${ }^{16}$

d) Siswa menjadi lebih tertarik dan lebih memahami terhadap materi pelajaran IPA yang disampaikan guru. ${ }^{17}$

e) Dapat menggugah hati siswa akan kebesaran Allah, yang berimplikasi pada siswa mulai merawat pohon dan tidak lagi merusaknya. ${ }^{18}$

f) Siswa tidak hanya pandai secara intelektual tapi juga pandai secara spiritual.

g) Manfaat bagi siswa ialah dapat meningkatkan nilai akademik menjadi lebih bagus dan secara tidak langsung akan meningkatkan nama baik sekolah. ${ }^{19}$

Empat dari lima orang guru IPA selalu mengajarkan nilai setiap kali mengajar IPA karena menurut salah satu dari guru tersebut bahwa tanggung jawab guru adalah sebagai pendidik bukan hanya pengajar, sedangkan seorang guru menyatakan tidak setiap pertemuan mengajarkan nilai karena tergantung pada tema materi yang diajarkan. ${ }^{20}$

b. Guru IPS

- Guru I (mewakili daerah Jakarta Pusat)

Guru ini adalah Sarjana Ekonomi, dengan lama mengajar 9 tahun. Pengalaman mengajar mata pelajaran lain ketika mengajar privat. Di samping itu, juga mengajar mata pelajaran IPS dan PKn pada sebuah Sekolah Dasar. Untuk mata pelajaran IPS, PKn, dan Bimbingan Konseling sendiri sudah diajarkan selama 3 tahun.

- Guru II (mewakili daerah Jakarta Utara)

Guru ini adalah Sarjana Agama dan sekarang sedang kuliah magister, mengajar selama 17 tahun, 10 tahun sebagai guru kelas.

- Guru III (mewakili daerah Jakarta Timur)

\footnotetext{
${ }^{12}$ Hasil wawancara dengan guru IPA Jakarta Timur

${ }^{13}$ Hasil wawancara dengan guru IPA Jakarta Utara

${ }^{14}$ Hasil wawancara dengan guru IPA Jakarta Barat

${ }^{15}$ Hasil wawancara dengan guru IPA Jakarta Pusat
}

\footnotetext{
${ }^{16}$ Hasil wawancara dengan guru IPA Jakarta Utara

${ }^{17}$ Hasil wawancara dengan guru IPA Jakarta Utara

${ }^{18}$ Hasil wawancara dengan guru IPA Jakarta Selatan

${ }^{19}$ Hasil wawancara dengan guru IPA Jakarta Timur

${ }^{20}$ Hasil wawancara dengan guru IPA Jakarta Pusat
} 
Guru ini mengajar selama 6 tahun, dan baru 3 bulan mengajar mata pelajaran IPS. Di samping mata pelajaran IPS, mata pelajaran lain yang ditugaskan adalah Matematika, Bahasa Indonesia dan PLBJ.

- Guru IV (mewakili daerah Jakarta Barat)

Guru ini memulai karir mengajarnya dari 1987 sebagai tenaga honorer di berbagai MI, pada 2005 baru mengajar di sekolah ini. Untuk mata pelajaran IPS sendiri diajarkan baru sekitar 3 tahun, selain mengajar IPS guru ini juga mengajar mata pelajaran Bahasa Indonesia.

- Guru V (mewakili daerah Jakarta Selatan)

Guru ini adalah seorang Sarjana Pendidikan Islam yang mengajar dari 1994 dan langsung mengajar mata pelajaran IPS karena memiliki latar belakang pendidikan dari IPS, namun kadang-kadang mengajarkan mata pelajaran IPA, Agama, Matematika ketika menggantikan guru piket.

Adapun hasil wawancara dengan lima orang guru IPS yang merupakan perwakilan dari lima wilayah di DKI ditemukan bahwa dua orang guru pernah mendengar informasi tentang pendidikan nilai, yaitu satu orang guru mendapat informasi pada saat kuliah strata satu. Guru tersebut membuat kesimpulan bahwa, "Pendidikan nilai adalah pendidikan yang menanamkan unsut-unsur nilai yang ada dalam kehidupan hubungannya dengan mata pelajaran. Pada dasarnya pendidikan tidak hanya terkait dengan kepentingan kognitif saja, melainkan harus juga memiliki makna/nilai/sikap dan hidup”. ${ }^{21}$ Sedangkan satu orang guru IPS dari wilayah Jakarta Timur pernah mendengarkan informasi tersebut saat Diklat KTSP-DDTK dalam seminar tentang "Mengembangkan Kecerdasan Anak". 22 Sebaliknya ada tiga guru IPS yang belum pernah mendengar informasi tentang pendidikan nilai (guru IPS I, IV, dan V).

\footnotetext{
${ }^{21}$ Hasil wawancara dengan guru IPS Jakarta Utara

${ }^{22}$ Hasil wawancara dengan guru IPS Jakarta Timur
}

Beberapa nilai yang terkandung pada setiap mata pelajaran di sekolah di antaranya adalah: toleransi, persatuan dan kesatuan NKRI, religius, menghargai antar umat beragama dan HAM, kebersamaan, sopan santun, kerjasama, kreativitas, rela berkorban, semangat kebangsaan dan cinta tanah air serta lingkungan, kasih sayang, budi pekerti, tanggung jawab, kekeluargaan, disiplin, dan kekompakan.

Semua guru IPS menyatakan bahwa tidak ada mata pelajaran di sekolah yang bebas dari kandungan nilai. Karena semua mata pelajaran mengajarkan siswa menjadi lebih baik dari sebelumnya. Dan sudah menjadi kewajiban sekolah menanamkan sikap yang baik pada siswa. Biasanya di awal pelajaran guru menjelaskan apa manfaat dari materi yang akan dipelajari.

Menurut pernyataan para guru IPS, beberapa nilai yang terkandung dalam mata pelajaran IPS di antara nya adalah: toleransi, religius, persatuan, kebersamaan, tanggung jawab, dan semangat kebangsaan. Untuk nilai semangat kebangsaan dapat ditanamkan dengan cara menghargai dan mengenang jasa para pahlawan seperti pada pelajaran negara-negara di mana setiap negara memiliki budaya, agama, adat istiadat tersendiri dan perbedaan budaya bukan menjadi alasan untuk terpecah belah. Nilai lain yang ditanamkan yakni, cinta tanah air melalui memahami wilayah NKRI dan bercerita tentang kerajaan-kerajaan di Indonesia. Selanjutnya nilai peduli sosial, rela berkorban, gemar membaca, serta sikap terbuka terhadap globalisasi karena segala informasi yang masuk harus disertai dengan rasa tanggung jawab, bersyukur atas nikmat Allah, dan disiplin dalam pemanfaatan produk globalisasi. Nilai kebersamaan penting diajarkan agar siswa tahu bagaimana menghargai orang lain dengan tidak mengejek di saat teman bertanya atau menanggapi, serta mampu bersosialisasi dengan teman dan lingkungan yang luas.

Terkait dengan manfaat mengajarkan IPS dengan memasukkan nilai-nilai yang terkandung 
di dalamnya, menurut para guru IPS adalah sebagai berikut:

a) Siswa menjadi lebih tahu nama-nama negara tetangga. ${ }^{23}$

b) Pembelajaran menjadi lebih menyenangkan. ${ }^{24}$

c) Mengingatkan diri sendiri apakah sudah mencerminkan/sesuai dengan nilai. ${ }^{25}$

d) Siswa tidak hanya mengerti apa yang dipelajari (kognitifnya saja), akan tetapi siswa juga harus memiliki pribadi yang unggul. ${ }^{26}$

e) Mengajar menjadi lebih bermakna karena siswa mau bekerja dengan keinginan sendiri dan mau bekerja sama dengan teman-temannya. ${ }^{27}$

f) Meringankan beban guru karena lambat laun siswa belajar mandiri dan mulai bertanggung jawab. Hal ini berimplikasi pada meningkatnya prestasi sekolah. ${ }^{28}$

g) Siswa menjadi lebih dekat dengan temannya, lebih peka terhadap kondisi yang ada di sekelilingnya, lebih sopan, dan jika dihubungkan dengan agama akan lebih rajin beribadah. ${ }^{29}$

h) Siswa lebih mengerti makna yang diajarkan sehingga dapat bersikap menjadi lebih baik lagi. ${ }^{30}$

Dari hasil wawancara juga ditemukan bahwa mayoritas guru IPS selalu mengajarkan nilai setiap kali mengajarkan konten IPS. Beberapa alasan yang disampaikan para guru di antaranya adalah: pertama, karena mendidik adalah menanamkan nilai; ${ }^{31}$ kedua, karena hakikat tujuan pembelajaran ialah menjadikan anak lebih baik dalam hidupnya. ${ }^{32}$ Namun ada

\footnotetext{
${ }^{23}$ Hasil wawancara dengan guru IPS Jakarta Pusat

${ }^{24}$ Hasil wawancara dengan guru IPS Jakarta Pusat

${ }^{25}$ Hasil wawancara dengan guru IPS Jakarta Utara

${ }^{26}$ Hasil wawancara dengan guru IPS Jakarta Utara

${ }^{27}$ Hasil wawancara dengan guru IPS Jakarta Barat

${ }^{28}$ Hasil wawancara dengan guru IPS Jakarta Timur

${ }^{29}$ Hasil wawancara dengan guru IPS Jakarta Barat

${ }^{30}$ Hasil wawancara dengan guru IPS Jakarta Selatan

${ }^{31}$ Hasil wawancara dengan guru IPS Jakarta Utara

${ }^{32}$ Hasil wawancara dengan guru IPS Jakarta Timur
}

juga guru IPS yang mengajarkan nilai tergantung konten materinya karena menurutnya kadangkadang tidak terlihat nilai yang terkandung di dalamnya dan merasa kesulitan mencari nilai yang tersembunyi tersebut. ${ }^{33}$ Di samping itu ada juga guru IPS yang menyatakan bahwa secara umum penanaman nilai sudah menjadi tugas guru PAI sedangkan guru-guru lainnya hanya mengingatkan saja misalnya pada nilai kejujuran. ${ }^{34}$

2) Data Dokumen Rencana Pelaksanaan Pembelajaran

a. Guru IPA

- Guru I (mewakili daerah Jakarta Pusat)

Berdasarkan contoh RPP yang sudah dibuat oleh guru dapat digambarkan bahwa:

- Pada tujuan pembelajaran belum tergambar tentang nilai yang akan disampaikan.

- Pada kolom karakter siswa yang diharapkan sudah tercantum rencana penanaman nilai, seperti: kerja keras, kreatif, mandiri, rasa ingin tahu, peduli lingkungan.

- Pada kegiatan apersepsi belum muncul penanaman nilai.

- Pada kegiatan inti belum tergambar tentang nilai-nilai yang akan dikembangkan dalam proses belajar mengajar secara eksplisit sebagaimana rencana di awal, walaupun ada beberapa kegiatan yang sebenarnya bisa memunculkan nilai, yakni pada saat praktikum dan menjelaskan konten.

- Pada kegiatan penutup belum muncul nilai yang akan dikembangkan.

- Pada aspek penilaian, walaupun sudah memasukkan beberapa Nilai Budaya dan Karakter Bangsa, namun instrumen/soal yang dikembangkan belum sesuai.

- Guru II (mewakili daerah Jakarta Utara)

\footnotetext{
${ }^{33}$ Hasil wawancara dengan guru IPS Jakarta Barat

${ }^{34}$ Hasil wawancara dengan guru IPS Jakarta Pusat
} 
Berdasarkan contoh RPP yang sudah dibuat oleh guru dapat digambarkan bahwa:

- Pada indikator dan tujuan pembelajaran belum tergambar tentang nilai yang akan disampaikan.

- Pada kolom karakter siswa yang diharapkan sudah tercantum rencana penanaman nilai, seperti: disiplin, perhatian, tekun, tanggung jawab dan ketelitian.

- Pada kegiatan apersepsi belum muncul penanaman nilai.

- Pada kegiatan inti belum tergambar tentang nilai-nilai apa yang akan dikembangkan dalam proses belajar dan mengajar secara eksplisit.

- Pada kegiatan penutup belum muncul nilai yang akan dikembangkan.

- Pada aspek penilaian, belum muncul aspek nilai yang akan dikembangkan.

- Guru III (mewakili daerah Jakarta Timur)

Berdasarkan contoh RPP yang sudah dibuat oleh guru dapat digambarkan bahwa:

- Pada indikator dan tujuan pembelajaran belum tergambar tentang nilai yang akan disampaikan.

- Pada kolom karakter siswa yang diharapkan belum muncul rencana penanaman nilai.

- Pada kegiatan apersepsi belum muncul penanaman nilai.

- Pada kegiatan inti belum tergambar tentang nilai-nilai apa yang akan dikembangkan dalam proses belajar dan mengajar secara eksplisit.

- Pada kegiatan penutup belum muncul nilai yang akan dikembangkan.

- Pada aspek penilaian, instrumen yang dikembangkan belum menyentuh aspek nilai yang akan dikembangkan.

- Guru IV (mewakili daerah Jakarta Barat)
Berdasarkan contoh RPP yang sudah dibuat oleh guru dapat digambarkan bahwa:

- Pada indikator dan tujuan pembelajaran belum tergambar tentang nilai yang akan disampaikan.

- Pada kolom karakter siswa yang diharapkan belum muncul rencana penanaman nilai.

- Pada kegiatan apersepsi belum muncul penanaman nilai.

- Pada kegiatan inti belum tergambar tentang nilai-nilai apa yang akan dikembangkan dalam proses belajar mengajar secara eksplisit.

- Pada kegiatan penutup belum muncul nilai yang akan dikembangkan.

- Pada aspek penilaian, belum muncul aspek nilai yang akan dikembangkan.

Selatan)

- Guru V (mewakili daerah Jakarta

Berdasarkan contoh RPP yang sudah dibuat oleh guru dapat digambarkan bahwa:

- Pada indikator dan tujuan pembelajaran belum tergambar tentang nilai yang akan disampaikan.

- Pada kolom karakter siswa yang diharapkan belum muncul rencana penanaman nilai.

- Pada kegiatan apersepsi sudah mencul penamanan nilai religi.

- Pada kegiatan inti belum tergambar tentang nilai-nilai apa yang akan dikembangkan dalam proses belajar mengajar secara eksplisit.

- Pada kegiatan penutup belum muncul nilai yang akan dikembangkan.

- Pada aspek penilaian, belum muncul aspek nilai yang akan dikembangkan.

\section{b. Guru IPS}

- Guru I (mewakili daerah Jakarta Pusat)

Berdasarkan contoh RPP yang sudah dibuat oleh guru dapat digambarkan bahwa: 
- Pada tujuan pembelajaran sudah tertulis keinginan guru untuk menyampaikan nilai ketelitian dalam membaca peta.

- Pada kolom karakter siswa yang diharapkan sudah tercantum rencana penanaman nilai, seperti: kreatif, komunikatif.

- Pada kegiatan apersepsi belum muncul penanaman nilai.

- Pada kegiatan inti sudah tergambar beberapa karakter yang akan disampaikan seperti disiplin, perhatian, tekun, jujur, teliti.

- Pada kegiatan penutup belum muncul nilai yang akan dikembangkan.

- Pada aspek penilaian, sudah memasukan beberapa aspek sikap yang akan dinilai, hanya instrumennya belum.

- Guru II (mewakili daerah Jakarta Utara)

Berdasarkan contoh RPP yang sudah dibuat oleh guru dapat digambarkan bahwa:

- Pada indikator dan tujuan pembelajaran belum tergambar tentang nilai yang akan disampaikan.

- Pada kolom karakter siswa yang diharapkan sudah tercantum rencana penanaman nilai, seperti: semangat kebangsaan, cinta tanah air, gemar membaca.

- Pada kegiatan apersepsi hanya ada pembiasaan meminta siswa untuk berdoa.

- Pada kegiatan inti belum tergambar tentang nilai-nilai apa yang akan dikembangkan dalam proses belajar mengajar secara eksplisit.

- Pada kegiatan penutup belum muncul nilai yang akan dikembangkan.

- Pada aspek penilaian, belum muncul aspek nilai yang akan dikembangkan.

- Guru III (mewakili daerah Jakarta Timur)

Berdasarkan contoh RPP yang sudah dibuat oleh guru dapat digambarkan bahwa:
- Pada indikator dan tujuan pembelajaran sudah muncul keinginan guru untuk menyampaikan nilai.

- Pada kolom karakter siswa yang diharapkan belum muncul rencana penanaman nilai.

- Pada kegiatan apersepsi belum muncul penanaman nilai.

- Pada kegiatan inti, siswa diminta mempraktikan cara merawat pohon (hal tersebut ialah bagian dari upaya penanaman nilai).

- Pada kegiatan penutup belum muncul nilai yang akan dikembangkan.

- Pada aspek penilaian, instrumen yang dibuat belum menyentuh aspek nilai yang akan dikembangkan.

- Guru IV (mewakili daerah jakarta barat)

Berdasarkan contoh RPP yang sudah dibuat oleh guru dapat digambarkan bahwa:

- Pada indikator dan tujuan pembelajaran belum tergambar tentang nilai yang akan disampaikan.

- Pada kolom karakter siswa yang diharapkan belum muncul rencana penanaman nilai.

- Pada kegiatan apersepsi belum muncul penanaman nilai.

- Pada kegiatan inti belum tergambar tentang nilai-nilai apa yang akan dikembangkan dalam proses belajar dan mengajar secara eksplisit.

- Pada kegiatan penutup belum muncul nilai yang akan dikembangkan.

- Pada aspek penilaian, belum muncul aspek nilai yang akan dikembangkan.

- Guru V (mewakili daerah Jakarta Selatan)

Berdasarkan contoh RPP yang sudah dibuat oleh guru dapat digambarkan bahwa:

- Pada indikator dan tujuan pembelajaran belum tergambar tentang nilai yang akan disampaikan. 
- Pada kolom karakter siswa yang diharapkan belum muncul rencana penanaman nilai.

- Pada kegiatan apersepsi sudah mencul penamanan nilai religi.

- Pada kegiatan inti baru mencantumkan aspek life skill.

- Pada kegiatan penutup mencantumkan aspek life skill.

- Pada aspek penilaian, belum muncul aspek nilai yang akan dikembangkan dan hanya menyediakan kolom penilaian untuk aspek afektif.

3) Analisis Data Wawancara dan Dokumen RPP

Berdasarkan data hasil wawancara dan dokumen RPP, dapat digambarkan bahwa secara umum dalam proses belajar mengajar guru memiliki keragaman dalam menanamkan nilai.

a. Guru IPA

- Guru I

Berdasarkan data hasil wawancara, guru sudah memahami makna dari karakter itu sendiri dan menyadari bahwa punya kepentingan menanamkan karakter. Hal ini dilakukan dengan memberikan teguran dan menjelaskan kepada siswa tentang apa yang seharusnya dilakukan jika ada siswa yang melakukan kesalahan.

Pada pertanyaan tentang pendidikan nilai (value), guru tidak mengetahui, setelah diarahkan oleh peneliti, guru baru menyadari nilai yang dimaksud dan mengatakan bahwa semua mata pelajaran tidak ada yang bebas nilai termasuk IPA. Nilai IPA yang ditanamkan adalah tanggung jawab, disiplin, kerja sama, keaktifan. Selanjutnya guru memberikan contoh waktu mengajarkan materi pubertas (saat menjelaskan tentang menstruasi) dan menanamkan bahwa wanita diberikan keistimewaan oleh Allah dengan rahim yang dimiliki sehingga tidak perlu merasa malu. Namun pada saat ditanyakan apakah akan berkomitmen dalam penanaman nilai, sang guru menjawab tergantung materinya, artinya guru belum memahami bahwa semua topik dalam IPA memiliki nilai.

Pada RPP yang dikembangkan, walaupun sudah dituliskan karakter siswa yang diharapkan seperti kerja keras, mandiri, rasa ingin tahu, peduli lingkungan, namun dalam kegiatan pembelajaran karakter tersebut tidak muncul sehingga dapat dikatakan bahwa karakter tersebut tidak disampaikan kepada siswa.

\section{- Guru II}

Berdasarkan data hasil wawancara, guru sudah memahami makna dari karakter itu sendiri dan menyadari bahwa punya kepentingan menanamkan karakter. Hal ini dilakukan dengan memberikan contoh seperti membiasakan mengucapkan salam, mencontohkan membuang sampah pada tempatnya, di samping itu dengan mengajarkan anak untuk mendoakan teman yang sedang sakit, membiasakan memulai dengan memberi salam dan berdoa.

Pada pertanyaan tentang pendidikan nilai (value), guru tersebut bingung, setelah diarahkan oleh peneliti barulah mengetahui bahwa semua mata pelajaran tidak ada yang bebas nilai termasuk IPA. Nilai IPA yang ditanamkan adalah ketekunan/ulet, respek/kepekaan, ketelitian, disiplin, kerjasama, dan tanggung jawab. Selanjutnya, guru memberikan contoh tentang kegiatan eksperimen di kelas, di mana pada diri siswa akan muncul kerjasama, ketelitian, dan tanggung jawab.

Pada RPP yang dikembangkan, walaupun sudah dituliskan karakter siswa yang diharapkan seperti disiplin, perhatian, tekun, tanggung jawab, dan ketelitian. Namun dalam kegiatan pembelajaran karakter tersebut tidak muncul sehingga dapat dikatakan bahwa karakter tersebut tidak disampaikan kepada siswa.

\section{- Guru III}

Berdasarkan data hasil wawancara, guru sudah memahami makna dari karakter itu sendiri dan menyadari bahwa punya kepentingan menanamkan karakter. Hal ini dilakukan dengan mendidik siswa untuk membaca shalawat sebelum belajar, membiasakan anak untuk 
mengucapkan salam sebelum dan sesudah belajar, membiasakan anak untuk meminta izin saat keluar masuk kelas, mentaati jam masuk sekolah. Guru ini sudah memberikan contoh yang tepat dalam menanamkan nilai.

Pada pertanyaan tentang pendidikan nilai (value), guru menjawab pernah pada saat mengikuti seminar dan mengetahui semua mata pelajaran tidak ada yang bebas nilai termasuk IPA. Nilai IPA yang ditanamkan adalah kerjasama, bersyukur atas nikmat Allah, tenggang rasa/toleransi, disiplin, religius, tanggung jawab, dan kekompakan. Selanjutnya guru memberikan contoh waktu meminta siswa untuk melestarikan lingkungan dengan menanam pohon dan dilakukan secara berkelompok pada saat itu saya mengajarkan kerja sama kepada siswa.

Pada RPP yang dikembangkan, guru belum memasukan nilai-nilai krakter yang akan ditanamkan dalam proses belajar mengajar, sehingga dapat dikatakan bahwa apa yang sudah disampaikan dalam wawancara belum terbukti dilaksanakan.

\section{- Guru IV}

Berdasarkan data hasil wawancara, guru sudah memahami makna dari karakter itu sendiri dan menyadari bahwa punya kepentingan menanamkan karakter. Hal ini dilakukan dengan memberikan contoh-contoh dalam pelaksanaan kehidupan sehari-hari, misalnya menghormati orang tua, kalau mau sekolah harus pamit, mematuhi peraturan sekolah, memakai seragam. Guru ini memberikan contoh yang tidak sesuai dengan apa yang disampaikan.

Pada pertanyaan tentang pendidikan nilai (value), guru menjawab belum pernah dan setelah diberikan penjelasan baru guru memahaminya dan mengatakan semua mata pelajaran tidak ada yang bebas nilai termasuk IPA. Nilai IPA yang ditanamkan adalah nilai religi. Selanjutnya guru memberikan contoh waktu menjelaskan materi tentang alat pernafasan, tata surya, dan anggota tubuh.

Pada RPP yang dikembangkan, guru belum memasukkan nilai-nilai karakter yang akan ditanamkan dalam proses belajar dan mengajar, sehingga dapat dikatakan bahwa apa yang sudah disampaikan dalam wawancara belum terbukti dilaksanakan.

\section{- Guru V}

Berdasarkan data hasil wawancara, guru sudah memahami makna dari karakter itu sendiri dan menyadari bahwa punya kepentingan menanamkan karakter. Hal ini dilakukan dengan mendidik siswa mengucapkan salam, serta mencium tangan.

Pada pertanyaan tentang pendidikan nilai (value), guru menjawab belum pernah dan setelah diberikan penjelasan baru guru memahaminya dan mengatakan semua mata pelajaran tidak ada yang bebas nilai termasuk IPA. Nilai IPA yang ditanamkan adalah nilai religi. Selanjutnya, guru memberikan contoh fotosintesis bahwa karena kekuasaan Allah menciptakan proses fotosintesis sehingga kita bisa tetap menghirup oksigen.

Pada RPP yang dikembangkan, guru belum memasukan nilai-nilai karakter yang akan ditanamkan dalam proses belajar mengajar, sehingga dapat dikatakan bahwa apa yang sudah disampaikan dalam wawancara belum terbukti dilaksanakan.

\section{b. Guru IPS \\ - Guru I}

Berdasarkan data hasil wawancara, guru sudah memahami makna dari karakter itu sendiri dan menyadari bahwa punya kepentingan menanamkan karakter. Hal ini dilakukan dengan memberikan contoh membuang sampah ke tempatnya dan memberikan nasihat/motivasi agar anak belajar dengan semangat.

Pada pertanyaan tentang pendidikan nilai (value), guru tidak mengetahui, setelah diarahkan oleh peneliti baru mengetahui bahwa semua mata pelajaran tidak ada yang bebas nilai termasuk IPS. Nilai IPS yang ditanamkan adalah menghargai, mengenang jasa para pahlawan, memahami wilayah negara-negara lain, toleransi, religius, persatuan, kebersamaan, menghargai 
antar umat beragama. Selanjutnya guru memberikan contoh waktu mengajarkan materi tentang kerajaan-kerajaan di mana terdapat nilai NKRI. Namun pada saat ditanyakan akan berkomitmen sang guru menjawab akan berkomitmen, namun untuk nilai agama akan disampaikan oleh guru agamanya langsung artinya guru masih mengkotakkan tanggung jawab dalam menyampaikan nilai (value).

Pada RPP yang dikembangkan, walaupun sudah dituliskan karakter siswa yang diharapkan seperti kreatif, komunikatif, begitu pun dalam kegiatan inti pembelajaran sudah dikembangkan karakter, namun berbeda dengan karakter yang diharapkan. begitupun dengan karakter yang ditanamkan tidak sesuai dengan kegiatan pembelajarannya.

\section{- Guru II}

Berdasarkan data hasil wawancara, guru sudah memahami makna dari karakter itu sendiri dan menyadari bahwa punya kepentingan menanamkan karakter. Hal ini dilakukan dengan memberikan contoh/keteladanan seperti menanamkan nilai cinta tanah air dilakukan dengan cerita dan penayangan gambar atau menjaga kebersihan.

Pada pertanyaan tentang pendidikan nilai (value), guru sudah mengetahuinya dan semua mata pelajaran tidak ada yang bebas nilai termasuk IPS. Nilai IPS yang ditanamkan adalah tanggung jawab, semangat kebangsaan, cinta tanah air, peduli sosial, rela berkorban, gemar membaca, toleransi. Selanjutnya, guru memberikan contoh zaman globalisasi yang tidak dapat kita hindari hanya kita harus bertanggung jawab untuk memilih dan memilah mana yang baik menurut kita. Contoh yang diberikan oleh guru belum menyinggung tentang nilai yang akan dikembangkan.

Pada RPP yang dikembangkan, walaupun sudah dituliskan karakter siswa yang diharapkan seperti disiplin, perhatian, tekun, tanggung jawab, ketelitian, namun dalam kegiatan inti pembelajaran karakter tersebut tidak tertulis sehingga dapat dikatakan bahwa karakter tersebut tidak disampaikan kepada siswa.

\section{- Guru III}

Berdasarkan data hasil wawancara, guru sudah memahami makna dari karakter itu sendiri dan menyadari bahwa punya kepentingan menanamkan karakter. Hal ini dilakukan dengan memberikan contoh-contoh dalam pelaksanaan kehidupan sehari-hari, misalnya menghormati orang tua, kalau mau sekolah harus pamit, mematuhi peraturan sekolah, memakai seragam. Guru ini memberikan contoh yang tepat.

Pada pertanyaan tentang pendidikan nilai (value), guru menjawab pernah pada saat mengikuti seminar dan mengetahui semua mata pelajaran tidak ada yang bebas nilai termasuk IPS. Nilai IPS yang ditanamkan adalah kerjasama, bersyukur atas nikmat Allah, tenggang rasa/toleransi, disiplin, agama, tanggung jawab, kekompakan. Selanjutnya, guru memberikan contoh waktu meminta siswa untuk melestarikan lingkungan menanam pohon dan dilakukan secara berkelompok pada saat itu saya mengajarkan kerja sama kepada siswa.

Pada RPP yang dikembangkan, guru belum memasukkan nilai-nilai karakter yang akan ditanamkan dalam proses belajar mengajar, sehingga dapat dikatakan bahwa apa yang sudah disampaikan dalam wawancara belum terbukti dilaksanakan.

\section{- Guru IV}

Berdasarkan data hasil wawancara, guru sudah memahami makna dari karakter itu sendiri dan menyadari bahwa punya kepentingan menanamkan karakter. Hal ini dilakukan dengan memberikan contoh-contoh dalam pelaksanaan kehidupan sehari-hari, misalnya menghormati orang tua, kalau mau sekolah harus pamit, mematuhi peraturan sekolah, memakai seragam. Guru ini memberikan contoh yang tidak sesuai dengan apa yang disampaikan.

Pada pertanyaan tentang pendidikan nilai (value), guru menjawab nilai religi, budi pekerti dan mengatakan semua mata pelajaran tidak ada yang bebas nilai termasuk IPS. Nilai IPS yang 
ditanamkan adalah nilai kebangsaan. Selanjutnya, guru memberikan contoh nilai kebangsaan, perbedaan budaya bukan menyebabkan kita terpecah belah. Namun ketika ditanya apakah akan berkomitmen untuk menanamkan nilai, guru mengatakan bergantung materinya artinya guru belum memahami secara utuh bahwa semua materi mengandung nilai.

Pada RPP yang dikembangkan, guru belum memasukkan nilai-nilai karakter yang akan ditanamkan dalam proses belajar dan mengajar, sehingga dapat dikatakan bahwa apa yang sudah disampaikan dalam wawancara belum terbukti dilaksanakan.

\section{- Guru V}

Berdasarkan data hasil wawancara, guru sudah memahami makna dari karakter itu sendiri dan menyadari bahwa punya kepentingan menanamkan karakter. Hal ini dilakukan dengan memberikan contoh-contoh dalam pelaksanaan kehidupan sehari-hari.

Pada pertanyaan tentang pendidikan nilai (value), guru menjawab nilai religi, budi pekerti dan mengatakan semua mata pelajaran tidak ada yang bebas nilai termasuk IPS. Nilai IPS yang ditanamkan adalah disiplin, saling menghargai, saling menghormati teman dengan tidak mengejek kalau teman bertanya atau menanggapi. Selanjutnya guru memberikan contoh yakni menghargai peninggalanpeninggalan pendahulu kita. Namun ketika ditanya apakah guru akan berkomitmen, guru menjawab, iya tetapi bergantung materinya artinya guru belum memahami bahwa semua konten memiliki nilai.

Pada RPP yang dikembangkan, guru sudah memasukan aspek life skill yang dikembangkan hanya saja tidak sinkron dengan kegiatan belajar yang dikembangkan.

\section{Pembahasan}

Berdasarkan hasil analisis data wawancara dan data dokumen RPP, terlihat bahwa semua guru sangat memahami makna dari karakter itu sendiri. Cara menanamkan karakter kebanyakan guru menjawab dengan memberikan contoh, memberikan pendidikan, dan memberikan pembiasaan. Hal ini sesuai dengan pandangan yang dikemukan oleh Zakaria bahwa strategi untuk menanamkan nilai teridiri dari memberi teladan, bahwa guru adalah orang yang pantas digugu dan ditiru, memberi informasi verbal, dengan nasehat dan penjelasan-penjelasan. ${ }^{35}$ Membiasakan siswa mengamalkan nilai-nilai yang ingin diintegrasikan dalam proses pembelajaran. Hanya pada aspek memberi ganjaran positif dan negatif belum muncul.

Begitu pula dengan karakter yang dikembangkan oleh guru hanya belum bervariasi, hal ini dapat dilihat pada proses wawancara karakter yang dikembangkan berupa mengucapkan salam, menghargai orang tua, kerjasama, tanggung jawab, disiplin, ketekunan. Terbukti kurang bervariasi, dan nilai yang disampaikan oleh guru dipengaruhi oleh ketidaktahuan guru tentang apa saja yang termasuk karakter yang dikembangkan dalam setiap pembelajaran.

Untuk pemahaman tentang pendidikan nilai, dari 10 guru yang diwawancarai hanya ada 2 guru yang mengerti makna dari pendidikan nilai itu sendiri. Untuk guru yang tidak tahu, alasannya karena belum pernah mendengar sedangkan yang sudah mengetahui mereka dapatkan pada kegiatan seminar atau dulu waktu di masa kuliah. Ketidaktahuan ini berdampak terhadap keterbatasan guru dalam menggali nilainilai apa yang terkandung dalam konten IPA dan IPS. Sehingga waktu ditanya tentang nilai apa yang terkandung dalam konten IPA dan IPS secara umum guru hanya memberikan jawaban yang tidak mendalam dan hanya pada hal-hal yang sifatnya muncul dalam kegiatan sehari-hari. Kerumitan tersendiri muncul dari guru-guru IPA yang tidak memiliki pengetahuan tentang makna yang terkandung dari konten itu sendiri.

\footnotetext{
${ }^{35}$ Teuku Ramli Zakaria, "Penilaian Sikap dan Nilai dalam Pembelajaran Matematika dan Sains”, h. 83.
} 
sedangkan yang IPS karena sudah berhubungan dengan perilaku sosial maka lebih banyak nilai yang di ketahui oleh guru IPS.

Kurang mampunya guru menggali nilai yang terkandung dalam konten IPA dan IPS ini berhubungan dengan pertanyaan bahwa apakah guru akan selalu berkomitmen untuk menanamkan nilai yang terkandung dalam konten IPA dan IPS, beberapa guru menjawab bahwa iya tetapi tergantung juga pada materinya, artinya guru tidak mengetahui bahwa setiap konten itu memiliki nilai dan ini berdampak pada ketidakmampuan menggali nilai yang terkandung dalam konten itu sendiri. Rendahnya kemampuan guru dalam menggali nilai itu sendiri disebabkan beberapa faktor antara lain, tidak adanya pelatihan-pelatihan bagi guru dalam memahami pendidikan nilai, latar belakang guru yang tidak sesuai dengan materi yang diajarkan, kurangnya penekanan dari pihak sekolah itu sendiri.

Kurangnya dukungan dan pemahaman ini tergambar dari RPP yang dikembangkan oleh guru, ada RPP yang sudah memasukan nilai karakter yang diharapkan, namun banyak pula yang belum memasukkan karakter yang diharapakan. Kemudian karakter yang dikembangkan oleh beberapa guru masih ada yang belum sesuai dengan kegiatan pembelajarannya, seperti pada contoh RPP salah satu guru: "pada saat siswa membaca peta lingkungan, guru menuliskan nilai karakternya yakni disiplin"

Contoh di atas memberikan gambaran bahwa beberapa karakter yang dituliskan dalam RPP tidak sesuai dengan kegiatan KBM itu sendiri. Begitu juga dengan penggalian nilai yang terkandung konten hanya sedikit nilai yang ditanamkan terutama yang berhubungan dengan nilai religi dan sosial, sedangkan nilai-nilai lain yang berhubungan dengan nilai praktis, intelektual, dan pendidikan.

\section{Penutup}

Dari hasil analisis data dan pembahasan dapat disimpulkan bahwa karakter yang sifatnya terlihat sudah dilakukan oleh guru walaupun belum bervariasi. Karakter yang dikembangkan oleh guru di antara nya seperti tanggung jawab, bekerja sama, saling menghormati, dan menghargai. Sedangkan untuk penggalian nilai yang terkandung dalam konten itu sendiri belum banyak dilakukan oleh guru. Hal ini terlihat dari beberapa RPP yang tidak menuliskan nilai karakter yang harus dikembangkan dalam pembelajaran.

\section{Daftar Pustaka}

Emzir, Analisis Data: Metodologi Penelitian Kualitatit, Jakarta:Rajawali Pers, 2011.

Gunawan, "Penerapan Model Pembelajaran Integrasi Imtaq untuk Meningkatkan Motivasi dan Hasil Belajar Fisika Siswa di MA Dakwah Islamiyah Putra Kediri”, dalam Jurnal Kependidikan LPPM IKIP Mataram 4(2), 2005.

Jarolimelc, John, Social Studies in Elementary Education. London: Mav Millan, 1986.

Lamijan, "Metode Dan Teknik Pendidikan Nilai", dalam Jurnal Inkoma 13(1), 2002.

Huberman, Michael, \& Miles, Mathew B, Qualitative Data Analysis: A Sourcebook of New Methods, (London: Sage Publication, Inc., 1984.

Yudianto, Suroso Adi, Strategi Belajar Mengajar Sains. Bandung: Fakultas Tarbiyah IAIN Bandung, 2001.

Zakaria, Teuku Ramli, "Penilaian Sikap dan Nilai dalam Pembelajaran Matematika dan Sains", dalam Makalah disampaikan dalam Seminar Nasional dengan Tema Pendidikan Nilai, Universitas Islam Negeri Jakarta, 2008. 